University of Nebraska - Lincoln

DigitalCommons@University of Nebraska - Lincoln

June 2004

\title{
Wheat Cultivar-Specific Selection of 2,4-Diacetylphloroglucinol- Producing Fluorescent Pseudomonas Species from Resident Soil Populations
}

\author{
M. Mazzola \\ USDA-ARS \\ Deanna L. Funnell \\ University of Nebraska-Lincoln, dfunnell2@unl.edu \\ J.M. Raaijmakers \\ Laboratory of Phytopathology, Section Molecular Ecology, Wageningen University, Wageningen, The \\ Netherlands
}

Follow this and additional works at: https://digitalcommons.unl.edu/plantpathpapers

Part of the Plant Pathology Commons

Mazzola, M.; Funnell, Deanna L.; and Raaijmakers, J.M., "Wheat Cultivar-Specific Selection of 2,4-Diacetylphloroglucinol-Producing Fluorescent Pseudomonas Species from Resident Soil Populations" (2004). Papers in Plant Pathology. 37.

https://digitalcommons.unl.edu/plantpathpapers/37

This Article is brought to you for free and open access by the Plant Pathology Department at DigitalCommons@University of Nebraska - Lincoln. It has been accepted for inclusion in Papers in Plant Pathology by an authorized administrator of DigitalCommons@University of Nebraska - Lincoln. 


\title{
Wheat Cultivar-Specific Selection of 2,4-Diacetylphloroglucinol-Producing Fluorescent Pseudomonas Species from Resident Soil Populations
}

\author{
M. Mazzola ${ }^{1}$, D.L. Funnell ${ }^{1}$ and J.M. Raaijmakers ${ }^{2}$ \\ (1) USDA-ARS, 1104 N. Western Avenue, Wenatchee, WA 98801, USA \\ (2) Laboratory of Phytopathology, Section Molecular Ecology, Wageningen University, Wageningen, The Netherlands \\ Received: 6 October 2003 / Accepted: 22 December 2003 / Online publication: 24 August 2004
}

\begin{abstract}
An emerging body of evidence indicates a role for plant genotype as a determinant of the species and genetic composition of the saprophytic microbial community resident to the rhizosphere. In this study, experiments were conducted to determine the capacity of five different wheat cultivars to enhance resident populations and support introduced strains of 2,4-diacetylphloroglucinol (2,4-DAPG)-producing fluorescent pseudomonads, a group of bacteria known to provide biological control of several soilborne diseases. When soils were cropped with three successive 28-day growth cycles of wheat, the 2,4DAPG-producing strains were consistently recovered from the rhizosphere of the cultivar Lewjain, and commonly were present at populations higher than those recovered from other wheat cultivars. Based on restriction fragment length polymorphism and sequence analyses of phlD, a key gene involved in 2,4-DAPG production, two previously undefined phlD+ genotypes, referred to as genotypes PfZ and PfY, were discovered. Wheat cultivar Lewjain was the primary source of genotype PfY while cultivar Penawawa yielded the majority of genotype PfZ. Based on 16S rDNA sequence analysis, both new phlD genotypes were classified as $P$. fluorescens. Comparison of the rhizosphere competence of 2,4-DAPG-producing P. fluorescens Q2-87 (genotype B) and P. fluorescens LR3-A28 (genotype PfY) showed that both strains persisted at similar populations in the rhizosphere of all cultivars tested over a 30 day period
\end{abstract}

Present address of D.L. Funnell: USDA-ARS, Wheat, Sorghum and Forage Research Unit, 344 Keim Hall, Univ. of Nebraska-East Campus, Lincoln, NE 68583, USA

Correspondence to: M. Mazzola; E-mail: mazzola@tfrl.ars.usda.gov when introduced as a seed inoculant. However, when strain LR3-A28 was applied as a soil inoculant, this strain was recovered at higher populations from the rhizosphere of wheat cultivar Lewjain than from the rhizospheres of two other cultivars. No cultivar effects were shown for strain Q2-87. Collectively, these results add further to evidence indicating a degree of specificity in interactions between plant cultivars and specific members of the saprophytic microbial community. Furthermore, as 2,4DAPG-producing fluorescent Pseudomonas spp. have a central role in the spontaneous reduction in severity of take-all disease of wheat in response to continuous wheat monoculture, we postulate that the use of specific cultivars, such as Lewjain, which possess a superior capacity to enhance resident soil populations of these bacteria may have potential to reduce the length of the monoculture period required to induce natural suppressiveness of soils toward this disease.

\section{Introduction}

The relative contribution of soil type and plant in determining composition of soil microbial communities has been debated. However, considerable evidence suggests that in the specific environment of the rhizosphere the plant plays a significant role in influencing attributes of the bacterial community $[5,16,17,24,31]$. Mazzola and $\mathrm{Gu}$ [28] demonstrated that composition of the fluorescent pseudomonad population in soil and the rhizosphere of apple was modified through prior cultivation of apple orchard soils with wheat. Cropping of soils with any of five different wheat cultivars enhanced populations of fluorescent pseudomonads recovered from these soils in a similar fashion. However, the genetic composition of this bacterial community recovered from soil and the rhizosphere of apple, and its capacity to 
inhibit in vitro growth of the pathogen Rhizoctonia solani AG 5, was dependent upon the wheat cultivar cropped prior to planting apple $[8,28]$.

Numerous studies have demonstrated the capacity of specific nonsymbiotic rhizobacteria to protect roots from infection by plant pathogenic fungi [51, 53]. Among these, fluorescent Pseudomonas spp. with the capacity to produce the antibiotic 2,4-diacetylphloroglucinol (2,4DAPG) have been shown to provide biological control of several important soilborne fungal plant pathogens when introduced as an inoculant [10, 21], and also have a functional role in the natural plant-induced development of soil suppressiveness to certain soilborne diseases (reviewed in Weller et al. [52]). One system that has been explored extensively is the spontaneous decline in the severity of take-all of wheat, incited by Gaeumannomyces graminis var. tritici, which often is observed after a severe outbreak of the disease for one or two crops early in a wheat monoculture cropping sequence. This phenomenon has been termed take-all decline. Although numerous biological and chemical elements have been put forth as the operative factors responsible for take-all suppressive soils $[4,52]$, a broad series of studies has provided convincing evidence for the predominant role of 2,4DAPG-producing fluorescent pseudomonads in take-all decline in certain geographic regions $[29,38,40,41,48]$.

The existence of disease suppressive soils was first recognized over 100 years ago, and the mechanisms by which pathogen suppression occurs have been the focus of study for nearly four decades. Although much progress has been made toward understanding the biology of constitutive and induced suppressive soils [2, 24, 41, 49], significant difficulty has been encountered in moving this knowledge into field level disease management. As the induction of soil suppressiveness is mediated through transformations in soil microbial communities $[19,28$, $40,52]$, it is plausible that opportunities exist to manage the phenomenon, and perhaps hasten the onset of the disease-suppressive state.

It was previously shown that, in response to cropping of apple orchard soils with wheat, the species and genetic composition of the fluorescent pseudomonad population will vary in a cultivar-dependent manner [27, 28]. Achieving a threshold population density of 2,4-DAPGproducing fluorescent pseudomonads in wheat-field soils is essential to the development of take-all decline [41]. Thus, identification of wheat genotypes with a superior capacity to select for resident populations of 2,4-DAPGproducing fluorescent pseudomonads could enhance the viability of a management scheme to utilize induced soil suppressiveness as a means to control take-all of wheat.

The objective of this research was to determine whether wheat cultivars differed in their capacity to select, both quantitatively and qualitatively, for 2,4-DAPGproducing fluorescent pseudomonads from resident soil microbial communities. Population densities of 2,4DAPG-producing pseudomonads were monitored by colony hybridization followed by PCR. The genotypic composition of the 2,4-DAPG-producing pseudomonad population recovered from different wheat cultivars was characterized by restriction fragment length polymorphism analysis of the phlD gene followed by sequence and phylogenetic analyses of newly selected $p h l D^{+}$genotypes. Finally, the capacity of two genotypically distinct 2,4DAPG-producing strains to colonize different wheat cultivars was assessed.

\section{Methods}

Soils. Studies were conducted in soils obtained from the Columbia View Research and Demonstration (CV) orchard located $19.2 \mathrm{~km}$ north of East Wenatchee, WA; the Wenatchee Valley College Auvil Research and Demonstration (WVC-A) orchard located $6.4 \mathrm{~km}$ east of East Wenatchee, WA; and the Wenatchee Valley College Sunny Slope (WVC-SS) orchard located in Wenatchee, WA. Microbial attributes of these soils, including composition of the fluorescent Pseudomonas spp. population, have been extensively characterized [22, 23, 27, 28]. Soils were collected in October of 2000, 2001, and 2002 at a depth of 10 to $30 \mathrm{~cm}$. By October 2002, apple had been cropped for 23, 7, and 46 years at the CV, WVC-A, and WVC-SS, respectively. The WVC-A site had been cropped to continuous wheat monoculture prior to orchard establishment in 1995.

Wheat Cultivars and Cropping of Soils. Wheat used in these studies included the cultivars Eltan, Hill-81, Lewjain, Madsen, and Penawawa. All cultivars are soft white winter wheat, with the exception of Penawawa, which is a soft white spring wheat. All seeds were obtained from the Washington State Crop Improvement Association, Foundation Seed Service, Washington State University, Pullman, WA. Seeds were not treated prior to planting.

Soils were dispensed into plastic pots $(3.8 \mathrm{~L}$ volume, $16 \mathrm{~cm}$ diameter) and seeds (10 g) of an individual wheat cultivar were sown in each pot with a total of four pots per cultivar. Seeds were covered with soil to a depth of $1 \mathrm{~cm}$. Pots were arranged in a completely randomized design on a greenhouse bench and plants were grown for 28 days at 18 to $22^{\circ} \mathrm{C}$ with supplemental lighting to maintain a minimum photoperiod of $12 \mathrm{~h}$. Plants were watered at 3-day intervals and were not fertilized during the course of plant growth. At the conclusion of the 28day growth cycle, plant shoots were excised at the soil surface and discarded. The contents of an individual pot were decanted and cultivated by hand to disrupt the wheat root system. Soils were dispensed back into the 
original pot and were reseeded with the same wheat cultivar. A total of three wheat growth cycles each 28 days in duration were used in all experiments.

Isolation of Fluorescent Pseudomonas spp. Fluorescent pseudomonads were recovered from the root systems of wheat harvested after the completion of the third growth cycle. Pots were inverted and wheat plants were separated from the soil. A composite sample consisting of five plants was selected for each pot, and soil loosely adhering to the root systems was detached by shaking. A 0.5-g composite root sample was excised from the five plants and placed in $10 \mathrm{~mL}$ sterile distilled water. Roots and associated rhizosphere soil were vortexed for $60 \mathrm{~s}$. Serial dilutions of the resulting root wash were plated on King's medium B (KB) agar amended with ampicillin $\left(100 \mu \mathrm{g} \mathrm{mL} \mathrm{m}^{-1}\right)$, chloramphenicol $(13 \mu \mathrm{g}$ $\left.\mathrm{mL}^{-1}\right)$ and cycloheximide $\left(75 \mu \mathrm{g} \mathrm{mL} L^{-1}\right)\left(\mathrm{KB}^{+}\right)$[45]. Plates were incubated at $28^{\circ} \mathrm{C}$ for $72 \mathrm{~h}$, at which time fluorescent colonies were counted. For each of the four root wash suspensions, 15 fluorescent pseudomonads were randomly selected and transferred to fresh $\mathrm{KB}^{+}$agar plates. Direct detection of 2,4-DAPG-producing fluorescent pseudomonads in the population recovered from wheat root systems was conducted through extraction and amplification of DNA from individual isolates as described below.

Detection and Quantification of 2,4-DAPG-Producing Fluorescent Pseudomonas spp. 2,4-DAPG-producing fluorescent pseudomonads were identified via detection of phlD, which is a key gene in the biosynthesis of 2,4DAPG. For each wheat cultivar, total DNA was extracted from the 60 individual fluorescent pseudomonad isolates using a modification of the method developed by Raaijmakers et al. [40] as previously described [28]. The oligonucleotide primers Phl2a and Phl2b [40] developed from conserved sequences within phlD were used in amplification reactions. DNA was amplified in $50-\mu \mathrm{L}$ volumes containing $1 \mu \mathrm{L}$ of the heat-lysed cell suspension, $1 \times$ PCR buffer, $200 \mu \mathrm{M}$, of each deoxynucleoside triphosphate, $1.5 \mathrm{mM} \mathrm{MgCl}_{2}$, each primer at $0.1 \mu \mathrm{M}$, and $2.5 \mathrm{U}$ AmpliTaq Gold (Applied Biosystems). Samples were amplified in a DNA GENE Amp 9700 thermal cycler (PerkinElmer, Norwalk, CT) using conditions previously described [40]. Each PCR included a positive (Pseudomonas fluorescens strain Q2-87 [37]) and negative (phl P. fluorescens) control. Amplified DNA products were verified by electrophoresis of $10-\mu \mathrm{L}$ aliquots of PCR mixtures through $1.2 \%$ agarose gels in $1 \times$ TBE buffer and visualization following ethidium bromide treatment.

Alternatively, in separate experiments, 2,4-DAPGproducing fluorescent pseudomonads recovered from wheat roots were quantified by colony hybridization according to the methods developed by Raaijmakers et al. [40]. The phlD probe was generated by randomly primed labeling of PCR fragments with the nonradioactive digoxigenin system (Roche Diagnostics, Mannheim, Germany) using DNA from the 2,4-DAPG-producing strain $P$. fluorescens Q2-87 as the template. The probe was detected with anti-digoxigenin-AP-FAB fragments, and phlD + colonies were visualized using nitroblue tetrazolium/5-bromo-4chloro-3-indoyl phosphate substrate according to protocols provided by the supplier. Colonies that reacted positively were purified by plating on $\mathrm{KB}^{+}$ agar, DNA was isolated using the cell lysis method, and the presence of the phlD gene was confirmed by means of the PCR protocol described above.

Genotypic Diversity. Genetic composition of the 2,4-DAPG-producing fluorescent pseudomonad population recovered from wheat cultivars grown in WVC-A soil was characterized by restriction fragment length polymorphism analysis of the phlD gene. This gene is highly polymorphic [43]. The primers B2BF and BPR4 [30] were used to amplify DNA from $p h l D^{+}$isolates. These primers are highly conserved across isolates possessing the phlD gene and possess a lower level of identity than the Phl2A and Phl2B with other known prokaryotic sequences [30]. Amplification reactions were conducted using the conditions previously described [30]. Genotypes were defined by digesting the resulting phlD DNA fragments individually with HaeIII, TaqI, or HpaII (Invitrogen Carlsbad, CA) in reactions containing $10 \mu \mathrm{L}$ of the amplified product. Digestion products were separated on $1.5 \%$ agarose gels in $1 \times$ TBE and banding patterns were visualized by ethidium bromide staining. Isolates were classified based on the genotypes erected by McSpadden Gardener et al. [30].

Sequence Analysis of the phID Gene and 16S $r D N A$. The phlD genes from isolates representing two apparent new genotypes were subjected to sequence analysis. Individual DNA fragments, resulting from amplification reactions which employed the $\mathrm{Phl} 2 \mathrm{a}$ and Phl2b primers, were cloned into the vector pCR2.1TOPO (Invitrogen, Carlsbad, CA) and the resulting plasmid transformed into E. coli TOP10. Plasmid DNA was purified from E. coli using an Invitrogen S.N.A.P. miniprep kit. Sequencing was conducted on an ABI 377 automated sequencer using the dye terminator cycle sequencing ready reaction kit (PE Biosystems, Warrington, England). Each $20-\mu \mathrm{L}$ reaction contained $2 \mu \mathrm{g}$ of template DNA and 10 pmol of the T7 or M13 reverse primer. The phlD sequences from genotypes designated PfY and PfZ were deposited in GenBank under accession numbers AY391780 and AY391779, respectively. The primers $8 \mathrm{f}$ and 1406r [1] were used to amplify the $16 \mathrm{~S}$ rRNA gene from these same strains as previously de- 
scribed [8], and partial 16S rDNA sequences were obtained using the methods described above.

Phylogenetic Analysis. Alignment of the newly sequenced $p h l D$ genes with phlD homologs present in the database (GenBank) was performed with GeneDoc 2.6 [32] and ClustalW 1.8 [50]. Sequences were trimmed to identical length. Subsequent phylogenetic analysis of the phlD genes was performed with MEGA [11] using the neighbor-joining method with the Kimura-2-parameter model. For comparison purposes, similar analyses were performed with the maximum parsimony method. Confidence of the topology of the phylogenetic trees for the phlD gene and protein sequences was performed by bootstrap analysis on 1000 resamplings [6].

Colonization of Wheat Roots by Introduced 2,4DAPG-Producing Fluorescent Pseudomonas Strains. The capacity of the 2,4-DAPG-producing strains Q2-87 and LR3-A28 to colonize different wheat cultivars when introduced as a soil or seed inoculant was assessed. P. fluorescens strain Q2-87 was originally isolated from wheat grown in a take-all suppressive soil from a field near Quincy, WA, and is a representative of BOX genotype B. Strain LR3-A28 was isolated in this study from roots of the wheat cultivar Lewjain grown in WVC-A orchard soil and, based on comparison with phlD genotypes previously described, represents a new phlD genotype. Spontaneous rifampicin-resistant mutants were selected by plating wild-type strains on $\mathrm{KB}^{+}$agar amended with rifampicin $\left(100 \mu \mathrm{g} \mathrm{mL}^{-1}\right)$. Resulting colonies were cultured two additional times on rifampicinamended $\mathrm{KB}^{-}$agar. Isolates that possessed a stable phenotype and exhibited rapid growth on this medium were selected, and an isolate exhibiting growth rate in $1 / 10$ strength and full-strength $\mathrm{KB}$ broth equivalent to the wild-type strain was selected for use in these studies. Strains were cultivated overnight at $28^{\circ} \mathrm{C}$ in $\mathrm{KB}$ broth; cells were pelleted by centrifugation and washed twice in sterile distilled water. Cells were resuspended in sterile distilled water and $0.5 \%(\mathrm{w} / \mathrm{v})$ methylcellulose for use in soil and seed treatments, respectively.

Seeds of the wheat cultivars Eltan, Lewjain, and Penawawa were treated individually by mixing $25 \mathrm{~g}$ of seed with a 10-mL cell suspension of Q2-87 or LR3-A28. Treated seeds were air dried in a laminar-flow hood and seed populations of the respective strains were determined as previously described [26]. WVC-Auvil orchard soil was dispensed into tapered plastic tubes $(21 \mathrm{~cm}$ depth, $3.8 \mathrm{~cm}$ top diameter; Stuewe \& Sons, Inc., Corvallis, OR); three wheat seeds were placed on the soil surface and covered with vermiculite to a depth of $1 \mathrm{~cm}$. At emergence, each tube was thinned to a single wheat plant. Plants were grown at $24^{\circ} \mathrm{C}$ with a 16 -h photoperiod. Fourteen seedlings were harvested at 10, 20, and 30 days after planting, and populations of the introduced strain were determined as previously described [25].

For soil applications, bacterial strains were introduced to individual samples of WVC-Auvil orchard soil as an atomized mist resulting in an initial population density of approximately $10^{4}$ and $10^{5} \mathrm{cfu} \mathrm{g}^{-1}$ soil for strain LR3-A28 and Q2-87, respectively. Soils were dispensed into tapered plastic tubes and each cell was planted with five seeds of the wheat cultivar Eltan, Lewjain, or Penawawa, with 14 replicates for each wheat cultivar-bacterial strain treatment. Plants were grown for 28 days at $24^{\circ} \mathrm{C}$ with a 16 -h photoperiod. At harvest, plants and soil were removed from an individual cell and a $0.5 \mathrm{~g}$ bulk root sample with firmly adhering soil was collected. Shoots were excised and soil with the remaining wheat root system was decanted back into the cell. Each cell was replanted with five seeds of the same wheat cultivar and the growth/harvest cycle was repeated five times. Root samples with associated soil were placed in 10 $\mathrm{mL}$ sterile water and vortexed for $60 \mathrm{~s}$. Serial dilutions of the resulting root wash were plated onto $\mathrm{KB}$ agar amended with rifampicin $\left(100 \mu \mathrm{g} \mathrm{mL}^{-1}\right)$ and cycloheximide $\left(75 \mu \mathrm{g} \mathrm{mL}{ }^{-1}\right)$. Colonies were enumerated after incubation for $72 \mathrm{~h}$ at $28^{\circ} \mathrm{C}$.

Statistical Analysis. Population data were logtransformed prior to analysis. Percent data were transformed to arcsine-square root values prior to analysis. Data were subjected to analysis of variance and means separation using the Student-Newman-Keuls method. Statistical analyses were conducted using Sigma-Stat, version 2.0 (SPSS, San Rafael, CA).

\section{Results}

Size of the fluorescent Pseudomonas spp. population recovered from the rhizosphere of wheat was dependent upon the orchard soil in which wheat was cropped. Populations recovered from the rhizosphere of wheat cropped in WVC-Auvil and CV soils, averaging 7.82 and $6.81 \times 10^{7} \mathrm{cfu} \mathrm{g}^{-1}$ root, respectively, did not differ significantly. However, rhizosphere populations recovered from wheat cropped in WVC-SS soils were significantly $(P<0.001)$ lower and averaged $9.14 \times 10^{5} \mathrm{cfu}^{-1}$ root. For a given orchard soil, fluorescent pseudomonad rhizosphere populations did not vary significantly among the wheat cultivars examined (data not shown). $P h l D^{+}$ isolates were not detected (limit of detection $=10^{4} \mathrm{cfu}$ $\mathrm{g}^{-1}$ soil) among fluorescent pseudomonad populations recovered from any of the orchard soils prior to cropping with wheat.

As determined by direct amplification of isolates randomly selected after the third wheat cycle from serial dilutions ( $n=60$ per wheat cultivar; $n=300$ per soil), 
the fluorescent pseudomonad population recovered from the rhizosphere of wheat (all cultivars combined) cropped in WVC-Auvil soil possessed a significantly $(P<$ $0.05)$ greater proportion of 2,4-DAPG-producing strains relative to the population recovered from wheat cropped in CV or WVC-SS orchard soil. phlD ${ }^{+}$strains comprised $5.0 \%, 2.3 \%$, and $10.7 \%$ of the isolates evaluated from the rhizosphere of wheat cropped in CV, WVC-SS, and WVC-A soils, respectively.

From these populations, the relative proportion of $p h l D^{+}$isolates recovered from the wheat rhizosphere varied in a cultivar-dependent manner. The fluorescent Pseudomonas spp. population isolated from the rhizosphere of Lewjain commonly possessed a greater proportion of $p h l D^{+}$isolates relative to other wheat cultivars, regardless of the soil in which wheat was cropped (Fig. 1). In one experiment conducted in WVC-Auvil soil, phlD ${ }^{+}$isolates represented $28 \%$ (17 of 60 isolates) of the fluorescent pseudomonad isolates examined from the Lewjain rhizosphere as detected by direct PCR. In comparison, using the same method, 2,4-DAPG-producing strains were only recovered from the rhizosphere of Madsen in a single experiment conducted in WVC-Auvil soil. $\mathrm{PhlD}^{+}$isolates never exceeded $5 \%$ of the population recovered from the rhizosphere of Eltan and were not detected in the population examined by direct PCR amplification of individual isolates recovered from this cultivar when grown in WVC-SS orchard soil.

Similar results were obtained in studies where a phlD probe was used in colony hybridizations to examine the fluorescent pseudomonad community. Populations of phlD ${ }^{+}$fluorescent pseudomonads recovered from the wheat rhizosphere differed among the orchard soils examined. $P h l D^{+}$isolates were consistently detected in populations recovered from the rhizosphere of Lewjain regardless of the orchard soil in which wheat was cultivated (Table 1). With the exception of Lewjain, rhizosphere populations of $p h l D^{+}$fluorescent pseudomonads recovered from wheat cropped in WVC-SS orchard soil were below the limits of detection (Table 1). As observed in direct detection by amplification of DNA from randomly selected isolates, colony hybridization experiments demonstrated that wheat cropped in WVC-Auvil and CV orchard soils sustained greater densities of 2,4-DAPGproducing fluorescent pseudomonads than did wheat cultivated in WVC-SS soil.

Genotype Diversity of phID ${ }^{+}$Isolates from Different Wheat Cultivars. The genotypic diversity of the isolated phlD+ fluorescent pseudomonad population was determined by RFLP analysis of the phlD gene and classified based on previously erected genotypes [30]. The results showed that the genetic composition of the $p h l D^{+}$population varied among soils and, in certain instances, was dependent on the wheat genotype. All phlD ${ }^{+}$isolates

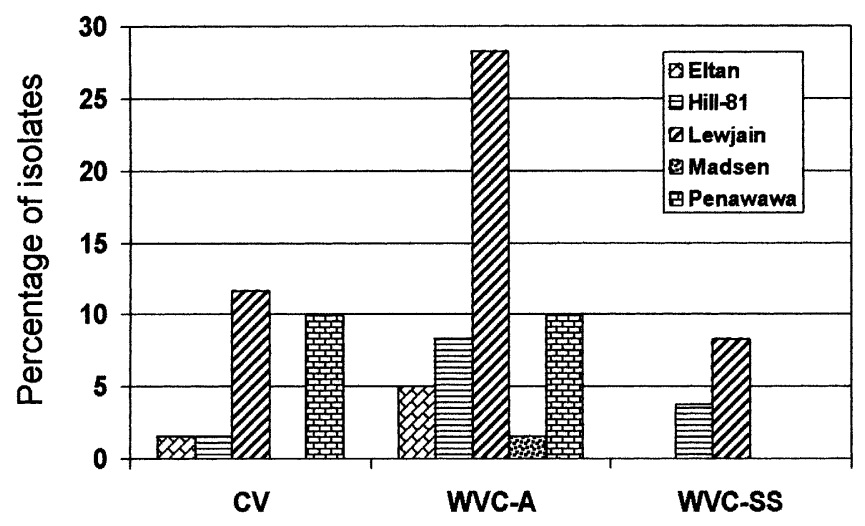

\section{Apple orchard soil}

Figure 1. Percentage of $p h l D^{+}$isolates determined by direct PCR of individual fluorescent Pseudomonas isolates $(n=60)$ recovered from the rhizosphere of different wheat cultivars at the end of three successive 28-day cycles of wheat cropping in Columbia View (CV), Wenatchee Valley College-Auvil (WVC-A), or Wenatchee Valley College-Sunnyslope (WVC-SS) apple orchard soils.

recovered from the rhizosphere of wheat cropped in CV orchard soil were defined as genotype A regardless of the wheat cultivar. The few isolates recovered from the rhizosphere of wheat cropped in WVC-SS all were identified as genotypes A or B based upon RFLP analysis of the phlD gene. In contrast, the population recovered from the rhizosphere of wheat cropped in WVC-Auvil orchard soil consisted of four different genotypes including genotypes $\mathrm{A}$ and $\mathrm{B}$, and two previously undefined genotypes referred to as PfY and PfZ (Figs. 2 and 3). Isolates defined as genotype $\mathrm{A}$ were recovered from the rhizosphere of all wheat cultivars grown in WVC Auvil soil. Wheat cultivar Lewjain was the primary source of isolates defined as genotype PfY while Penawawa yielded the majority of

Table 1. Population densities ( $\mathrm{cfu} \mathrm{g}^{-1}$ root) of $p h l D^{+}$fluorescent pseudomonads recovered from the rhizosphere of five different wheat cultivars grown in apple orchard soils

\begin{tabular}{llll}
\hline & \multicolumn{3}{c}{ Orchard $^{x}$} \\
\cline { 2 - 4 } Wheat cultivar & \multicolumn{1}{c}{$C V$} & \multicolumn{1}{c}{ WVC-A } & WVC-SS \\
\hline Eltan & ND & ND & ND \\
Hill-81 & $2.09 \times 10^{4} \mathrm{a}^{y}$ & ND & ND \\
Lewjain & $2.15 \times 10^{5} \mathrm{~b}$ & $2.75 \times 10^{5} \mathrm{a}$ & 12,500 \\
Madsen & $3.63 \times 10^{4} \mathrm{a}$ & ND & ND \\
Penawawa & $4.80 \times 10^{4} \mathrm{ab}$ & $3.20 \times 10^{5} \mathrm{a}$ & ND \\
\hline
\end{tabular}

${ }^{\mathrm{x}} \mathrm{CV}$ : Columbia View Research and Demonstration Orchard, Orondo; WVC-A: Wenatchee Valley College Auvil Research and Demonstration Orchard, E. Wenatchee; WVC-SS: Wenatchee Valley College Sunnyslope Orchard, Wenatchee, WA.

${ }^{y}$ Populations were determined after completion of three successive 28-day wheat cropping cycles by colony blot hybridization using the phlD probe. Each value is a mean consisting of six replicates. Statistical analyses were performed on log-transformed population densities. Means in the same column followed by the same letter are not significantly $(P>0.05)$ different. ND: Not detected; limit of detection $=10^{4} \mathrm{cfu} \mathrm{g}^{-1}$ root. 


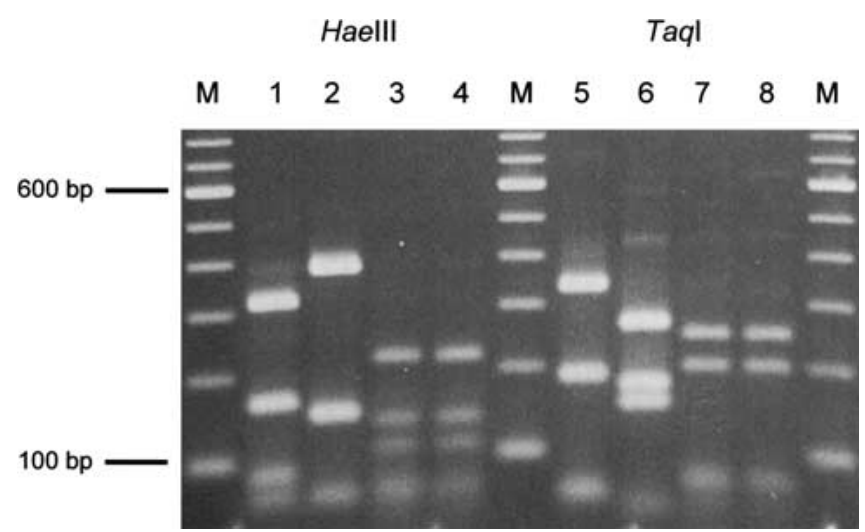

Figure 2. Restriction fragment length polymorphism analysis of the 629-bp phlD fragment amplified in reactions with the B2BF and BPR4 [29] primer pair. DNA was digested with HaeIII or TaqI and products were separated on a $2.0 \%$ agarose gel. The sizes of individual fragments were compared with 100-bp ladder (M). PCR was performed using template from lysed cells of the following isolates, lanes 1 and 5: Q2-87 (genotype B); lanes 2 and 6: HR3-A13 (PfY); lanes 3 and 7: PR3-A3 (PfZ); lanes 4 and 8: PR3-A52 (PfZ); lane 4: Q2-87.

isolates defined as genotype PfZ (Fig. 2). Sequence analysis of the $16 \mathrm{~S}$ rDNA placed representative isolates from both genotypes within $P$. fluorescens.

Sequence and Phylogenetic Analyses of phlD Genotypes PfY and PfZ. For two isolates representing phlD genotypes PfY and PfZ, a 745-bp fragment of the

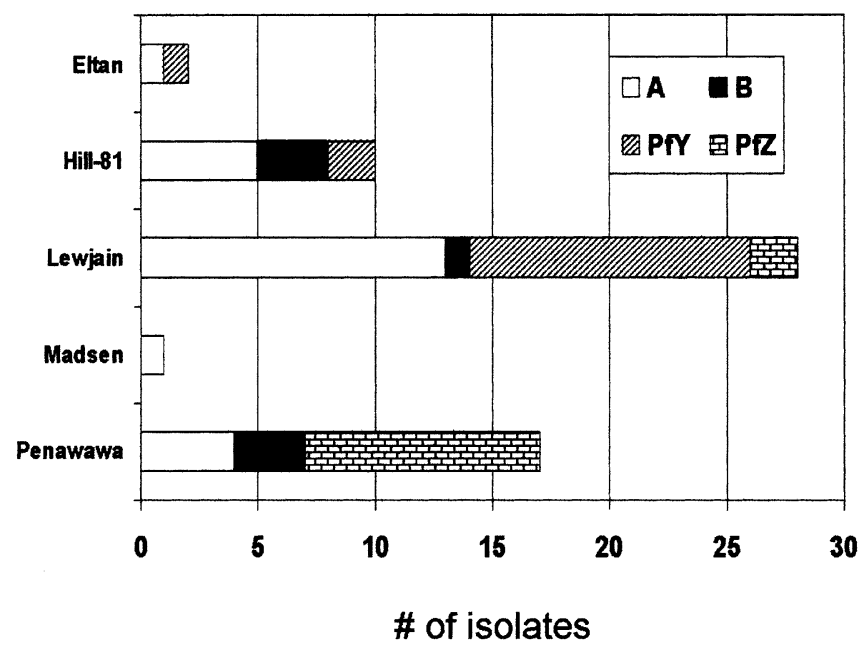

Figure 3. Distribution of phlD+ genotypes recovered from the rhizosphere of five wheat cultivars grown in Wenatchee Valley College-Auvil orchard soil. The population includes those fluorescent Pseudomonas obtained by plating serial dilutions of root washes on $\mathrm{KB}^{+}$and randomly selecting isolates for subsequent amplification with the $\mathrm{Phl} 2 \mathrm{a}$ and $\mathrm{Phl} 2 \mathrm{~b}$ primers to determine the presence of the phlD gene, as well as isolates detected by probing colony blots with the phlD probe. Genotypes A and B indicate BOX genotypes as defined by McSpadden Gardner et al. [30], and genotypes PfY and PfZ indicate new phlD genotypes.
Table 2. Bacterial species, strains, and phlD GenBank accession numbers used in the phylogenetic analyses

\begin{tabular}{|c|c|c|c|}
\hline Species & Strain/isolate & Code & $\begin{array}{c}\text { Accession } \\
\text { number }\end{array}$ \\
\hline \multirow[t]{26}{*}{ P. fluorescens } & $42-36$ & Pf4236 & AF396857 \\
\hline & $42-27$ & Pf4227 & AF396856 \\
\hline & $39-8$ & Pf398 & AF396855 \\
\hline & $37-27$ & Pf3727 & AF396854 \\
\hline & $22-27$ & Pf 2227 & AF396853 \\
\hline & $19-41$ & Pf1941 & AF396852 \\
\hline & $19-30$ & Pf1930 & AF396851 \\
\hline & $19-7$ & Pf197 & AF396850 \\
\hline & $18-33$ & Pf1833 & AF396849 \\
\hline & $11-18$ & Pf1118 & AF396848 \\
\hline & $7-37$ & Pf737 & AF396847 \\
\hline & $6-28$ & Pf628 & AF396846 \\
\hline & $3-1$ & Pf31 & AF396845 \\
\hline & F113 & PfF113 & AJ278811 \\
\hline & PILH1 & PfPILH1 & AJ278810 \\
\hline & PITR2 & PfPITR2 & AJ278809 \\
\hline & CM1'A2 & PfCM1A2 & AJ278808 \\
\hline & Q65C-80 & PfQ65c80 & AJ278807 \\
\hline & CHAO & PfCHA0 & AJ278806 \\
\hline & Pf-5 & PfPf5 & AF214457 \\
\hline & UP61 & PfUP61 & AF214108 \\
\hline & Q8r1-96 & PfQ8r196 & AF207693 \\
\hline & M1-96 & PfM196 & AF207692 \\
\hline & Q2-87 & PfQ287 & U41818 \\
\hline & HR3-A13 & PfY & This study \\
\hline & PR3-A52 & PfZ & This study \\
\hline P. putida & R62 & PpR62 & AJ515696 \\
\hline \multirow[t]{3}{*}{ P. corrugata } & 872 & Pc872 & AJ515694 \\
\hline & 711 & Pc711 & AJ515693 \\
\hline & 709 & Pc709 & AJ515692 \\
\hline Acidovorax facilis & R117 & AfR117 & AJ515695 \\
\hline Commamonas acidovorans & $\mathrm{R} 81$ & CaR81 & AJ515697 \\
\hline Uncultured bateria $(n=30)$ & & & $\begin{array}{l}\text { AF515662 to } \\
\text { AJ515691 }\end{array}$ \\
\hline
\end{tabular}

phlD gene was amplified, cloned, sequenced, and aligned to known phlD genes. Currently, 60 bacterial phlD sequences are present in the database of which 30 (GenBank accession numbers AJ515662 to AJ515691) were derived from uncultured bacteria (Table 2). Our phylogenetic analysis focused initially on comparison of the phlD gene sequences of PfY and PfZ isolates with 24 phlD gene sequences of other $P$. fluorescens isolates. These 24 sequences were selected as their sizes are approximately 650 to $700 \mathrm{bp}$, whereas the other phlD sequences present in the database are only approximately $230 \mathrm{bp}$. After alignment and trimming, $P$. fluorescens strain UP61 (accession number AF214108) was excluded from the phylogenetic analyses since its phlD sequence is substantially different from the other 23 phlD sequences, including those obtained from PfY and PfZ, thereby creating multiple gaps scattered across the entire sequence. Subsequent neighbor-joining and maximumparsimony analyses showed that the phlD genes found in PfY and PfZ isolates were significantly different from any of the reported phlD sequences (Fig. 4A). Interestingly, 


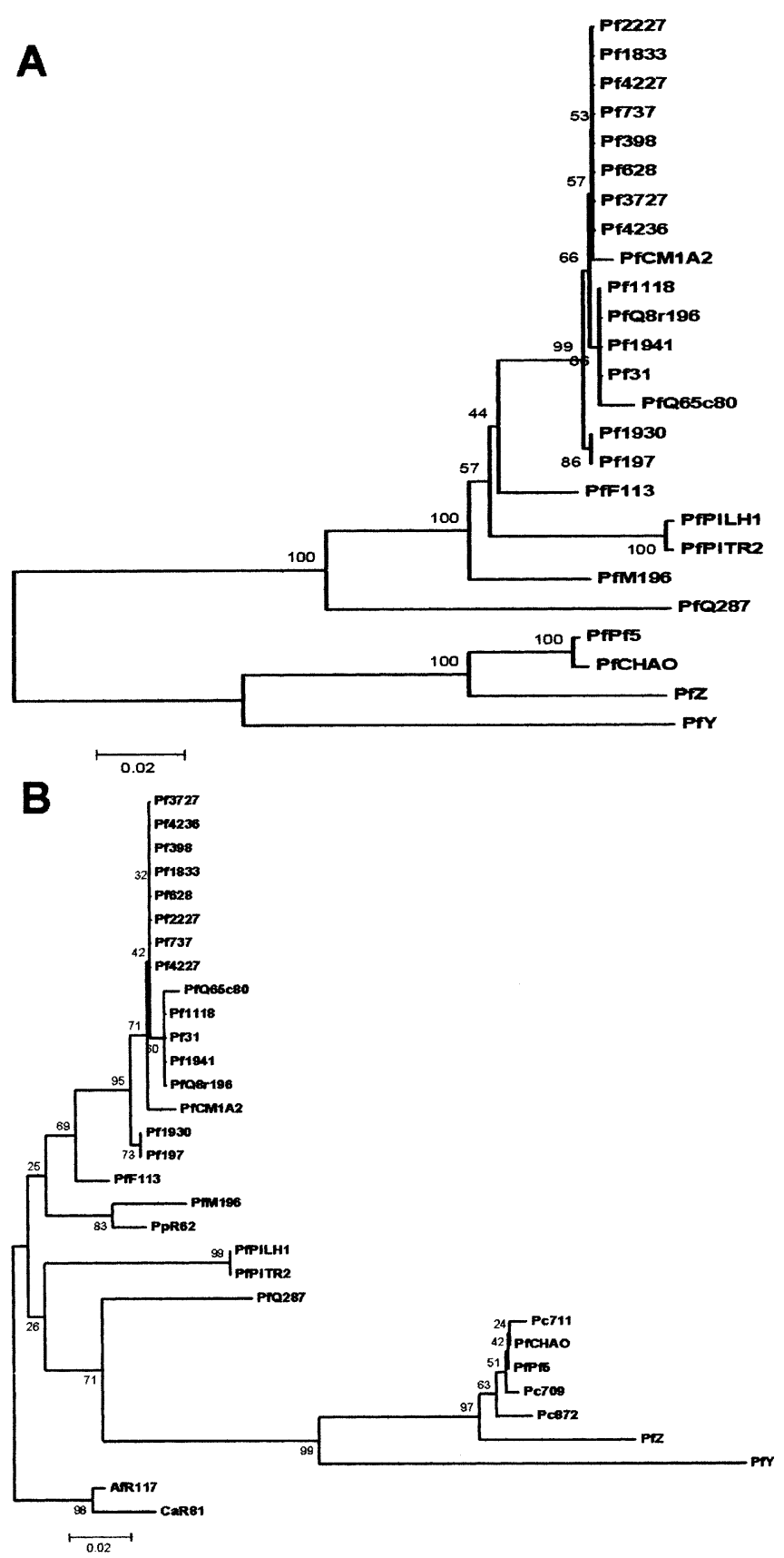

Figure 4. Phylogenetic trees generated with neighbor-joining using 670-bp phlD sequences from 25 strains of Pseudomonas fluorescens (A) and 210-bp phlD sequences from a total of 31 strains representing $P$. fluorescens, $P$. putida, P. corrugata, C. acidovorans, and A. facilis (B). The phylogenetic tree shown in panel A is unrooted, whereas the tree shown in panel B is rooted with the phlD sequence of $C$. acidovorans strain R81 (CaR81). Codes used for the bacterial species and strains/isolates are given in Table 2. Bootstrap values are indicated for each of the branches.

PfY and PfZ clustered close to each other and to phlD genes found in BOX genotype A strains CHA0 [10] and Pf-5 [33]. Also, analysis of the deduced protein sequences revealed that phlD from PfY and PfZ isolates are different from known PhlD sequences and closely related to those from strains CHA0 and Pf-5 (data not shown). After this initial analysis covering a relatively large part of the phlD gene, phylogenetic analysis was also performed with an additional six phlD sequences obtained from strains other than P. fluorescens, including three Pseudomonas corrugata isolates, one Pseudomonas putida isolate, one Acidovorax facilis isolate, and one Comamonas acidovorans isolate (Table 2). After alignment, phlD sequences were trimmed to $210 \mathrm{bp}$. In the phylogenetic analysis, the phlD sequence from $C$. acidovorans isolate $\mathrm{R} 81$ was used to root the tree. The results showed again that PfY and PfZ represent new phlD genotypes (Fig. 4B). Interestingly, the phlD genes obtained from the three $P$. corrugate isolates were highly similar to the phlD genes of strains CHA0 and Pf-5. Neighbor-joining and maximum-parsinomy analyses yielded similar results. Also analysis of the deduced protein sequences revealed that PfY and PfZ are different from known PhlD sequences and closely related to those from strains CHA0 and Pf-5 (data not shown). Final analysis with all 60 phlD sequences, including those obtained from uncultured bacteria, confirmed that PfY and PfZ represent two new phlD genotypes (data not shown).

Colonization of Wheat Cultivars by Two Genotypically Different 2,4-DAPG Producers. When introduced as a seed inoculant, 2,4-DAPG-producing fluorescent Pseudomonas strains Q2-87 (BOX genotype B) and LR3-A28 (genotype PfY) characteristically persisted in the rhizosphere at similar populations among the three wheat cultivars examined. Bacterial strains were established at initial populations of $\sim 4 \times 10^{7}$ cells seed $^{-1}$. Rhizosphere populations of strain Q2-87 or LR3-A28 exhibited a continuous decline over a 30-day period, and this trend transpired in a similar fashion for all wheat cultivars (data not shown). For strain Q2-87, populations declined from $\sim 4 \log \mathrm{cfu} \mathrm{cm} \mathrm{cm}^{-1}$ root at 10 days after planting to 2 $\log \mathrm{cfu} \mathrm{cm}^{-1}$ root at 30 days. Strain LR3-A28 followed a similar pattern declining from $\sim 5 \log$ to $2.5 \log \mathrm{cfu} \mathrm{cm}^{-1}$ root over the same time period. No significant differences in populations of these two strains were detected among wheat cultivars at any sampling point.

Similar population dynamics of strain Q2-87 applied directly to soil were detected in soils cropped with five successive cycles of the same wheat cultivar. Populations of strain Q2-87 declined from a maximum of $5 \mathrm{log}$ cfu $\mathrm{cm}^{-1}$ root after cycle 1 to a population below the level of detection for all wheat cultivars at the end of cycle 5 (Fig. 5A). No significant differences among three wheat cultivars in populations of Q2-87 were noted at any sampling. In contrast, rhizosphere populations of strain LR3-A28 recovered from Eltan and Penawawa remained rather static over the course of successive wheat cycling 


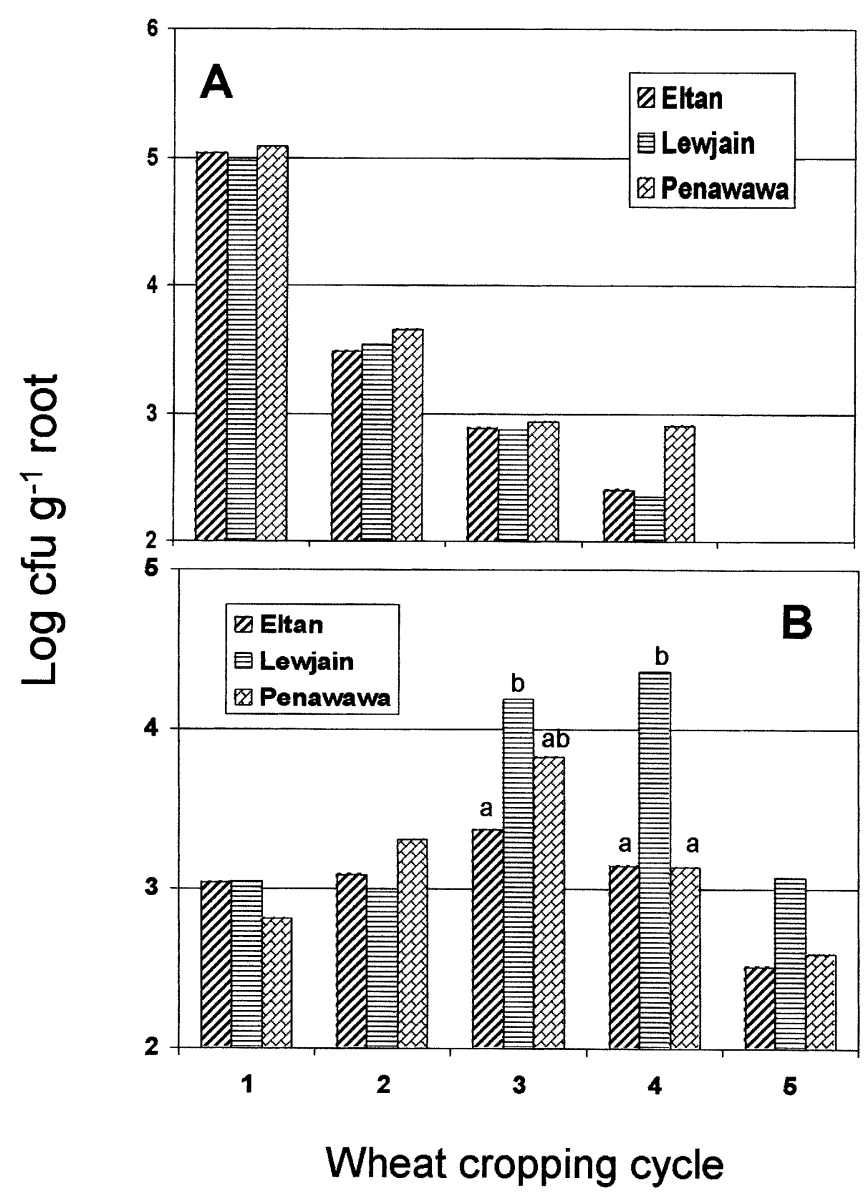

Figure 5. Mean population density of Pseudomonas fluorescens strain Q2-87 (A) and strain LR3-28A (B) recovered from the roots of wheat grown in Wenatchee Valley College-Auvil orchard soil for five successive cycles of 28 days each (A). Each mean consists of 14 replicates. Strain Q2-87 was not recovered from any wheat cultivar at the completion of cycle 5. For strain Q2-87, no significant $(P=0.05)$ differences were detected at any sampling period. For strain LR3-28A, means for the same cycle designated with the same letter are not significantly $(P=0.05)$ different.

(Fig. 5B). Moreover, populations of strain LR3-A28 recovered from Lewjain increased over the initial four wheat cycles to a density of $4.36 \mathrm{log} \mathrm{cfu} \mathrm{g}^{-1}$ root in cycle 4 (Fig. 5B). Significant differences among wheat cultivars were observed at cycles 3 and 4 when the population of strain LR3-A28 recovered from Lewjain was significantly larger than that recovered from either Eltan (cycle 3 and 4) or Penawawa (cycle 4). After three and four successive growth cycles, strain LR3-A28 established more than 10fold higher rhizosphere population densities in the rhizosphere of cultivar Lewjain than strain Q2-87 (Fig. 5A, B).

\section{Discussion}

Plants have an influential role in determining the species and genetic composition of soil microbial com- munities [7, 12]. Previous studies have demonstrated that composition of the fluorescent pseudomonad population will vary significantly within the rhizosphere of different plant hosts cultivated in the same soil [17] and will change dramatically overtime in response to changes in the crop species [23, 27]. The impact of plant species on composition of microbial communities is accepted, and there is emerging evidence that host genotype will have a significant influence on the structure and function of important elements of the saprophytic soil microbial community. As observed in this and previous studies [8], fluorescent pseudomonad populations are enhanced in a similar fashion by cropping soils with wheat regardless of the cultivar employed. However, the genetic and species composition of the fluorescent pseudomonad community recovered from the rhizosphere of wheat was found to vary among cultivars when grown in the same soil $[8$, 28]. In addition, expression of the 2,4-DAPG biosynthesis gene phlA in P. fluorescens CHA0 was found to differ among cultivars of maize [34].

As take-all decline functions in part through the enrichment of 2,4-DAPG-producing fluorescent Pseudomonas spp. and their activity in the wheat rhizosphere (reviewed in Weller et al. [52]), it is plausible that a wheat cultivar possessing the capacity to selectively enhance resident populations of these bacteria would encourage disease decline more readily than cultivars that do not select for these strains. In the current study, it was observed that wheat cultivars possessed a differential capacity to select for resident populations of 2,4-DAPGproducing fluorescent pseudomonads. When using either of two assessment methods, phlD ${ }^{+}$isolates invariably were detected among the population of fluorescent Pseudomonas spp. recovered from the rhizosphere of Lewjain. In several instances the population of 2,4DAPG-producing fluorescent pseudomonads recovered from this cultivar was significantly larger than that present in the rhizosphere of four other wheat cultivars examined. This trend was observed irrespective of soil in which wheat cycling was conducted. For all other wheat cultivars, 2,4-DAPG-producing fluorescent pseudomonads were not detected in one or more of the three soils examined, and recovery of $p h l D^{+}$isolates from the rhizosphere of cultivars Eltan or Madsen was atypical. A similar finding was obtained by $\mathrm{Gu}$ and Mazzola [8], where 2,4-DAPG-producing fluorescent pseudomonads, defined as genotype 9 by the methods employed in that study, represented $17-33 \%$ of the population recovered from the rhizosphere of apple seedlings planted in soils previously cropped with Lewjain, Penawawa, or Symphony, but represented only $0-7 \%$ of the isolates from apple grown in Eltan, Hill-81, or Madsen cropped soils.

These findings suggest that a continuous wheat monoculture cropping system which employed Lewjain 
could conceivably achieve a state of take-all decline more rapidly than with any of the other four wheat cultivars examined. However, one confounding factor to employing such a strategy may involve the genetic composition of the 2,4-DAPG-producing fluorescent Pseudomonas spp. population resident to a soil. In all three soils examined in this study, isolates representing BOX genotype A were recovered from roots of all five wheat cultivars tested. Interestingly, two other phlD genotypes, referred to as PfY and PfZ, were isolated. Based on RFLP and sequence analyses of phlD, PfY and PfZ represent two new phlD+ genotypes which are closely related to the phlD genotypes represented by $P$. fluorescens strains CHA0 and Pf-5. 16S rDNA sequence analysis confirmed that PfY and PfZ isolates were closely related to strains $\mathrm{CHA} 0$ and Pf-5. Wheat cultivar Lewjain was the primary source of genotype PfY while cultivar Penawawa yielded the majority of genotype PfZ. In contrast to the results obtained in this study, BOX genotype D isolates were previously found to predominate on roots of wheat grown in field soils exhibiting take-all decline in Washington [29, 42] and have been shown to displace genotype A isolates from soil and the rhizosphere when co-inoculated at equivalent populations [14]. Because of their superior colonization abilities, genotype $\mathrm{D}$ isolates provide a level of take-all control superior to genotype A isolates. Thus, even should the cultivar Lewjain enhance populations of 2,4-DAPG-producing isolates quantitatively, initial selection of an inferior genotype could result in a delay in the development of take-all decline. In this context, the ability of PfY and PfZ genotypes to control soilborne disease of wheat, and in particular take-all, needs to be established to further support this hypothesis.

As has been noted previously, the development of take-all decline may be influenced by multiple attributes of the agro-ecosystem $[44,52]$. In this study, it was rare to recover $p h l D^{+}$isolates from the rhizosphere of wheat grown in WVC-SS orchard soil, and populations of 2,4DAPG-producing fluorescent pseudomonads did not approach the threshold densities $\left(>10^{5} \mathrm{cfu} \mathrm{g}^{-1}\right.$ root $)$ necessary to achieve take-all decline [41]. In contrast, populations of $p h l D^{+}$fluorescent pseudomonads in the rhizosphere of one or more cultivars were greater than this threshold population when wheat was cropped for three successive cycles in CV or WVC-A orchard soils. This finding suggests that take-all decline could be expressed earlier in WVC-A and CV soils relative to WVC-SS soil.

Root colonization by introduced biocontrol rhizobacteria has been the subject of intense study as in many systems it has been deemed an essential element in determining the ultimate success of biological disease control [20]. The maintenance of a threshold population by an introduced biocontrol agent is known to be a factor in the ability to achieve effective disease suppression in certain systems $[9,39]$, including the application of phenazine or 2,4-DAPG-producing fluorescent pseudomonads for the control of take-all of wheat $[3,41]$. In the current study, no differences were observed among wheat cultivars in colonization of the rhizosphere by strain Q287 when introduced as either a seed or soil inoculant. Colonization of the wheat rhizosphere by strain LR3-A28 when applied to seed was similar for all cultivars. However, when applied to soil which was subsequently cropped to successive wheat cycles, strain LR3-A28 preferentially increased in the rhizosphere of Lewjain relative to Eltan and Penawawa for a period of time, prior to declining to similar populations during the final cropping cycle. Similarly, Okubara et al. [35] suggested a wheat cultivar variable response in colonization by $p h l D^{+}$ fluorescent pseudomonads based on the observation that the 2,4-DAPG producing strain Q8r1-96 was maintained in the rhizosphere of certain, but not all, wheat cultivars at significantly higher populations than strain Q2-87. Specific genotypes of 2,4-DAPG-producing fluorescent pseudomonads appear to preferentially colonize certain crop species [13,36]. These and other studies [46, 47] indicate that linking a specific plant genotype with an appropriate genotype of a biocontrol rhizobacterium may enhance the efficacy of the disease control system.

Several recent studies have demonstrated the impact of vegetation on composition of the resident soil microbiota $[7,12,17]$ and have indicated an important role for host genotype in determining the efficacy of resident and introduced microorganisms for the control of soilborne diseases $[18,28,34,46]$. Management of the resident soil microbial community holds promise as a means to alleviate the activity of soilborne plant pathogens [28]. Such a system could employ specific cropping sequences to induce soil suppressiveness. However, a major limitation to the use of this management strategy is the time frame required to achieve an economically viable level of disease control. Again, the evidence garnered to date has demonstrated a plant-genotype-dependent capacity to select for specific functional microbial elements that contribute to soil suppressiveness $[15,28]$. We postulate that selection of the appropriate plant genotype could substantially reduce the time frame required to induce suppressiveness to a specific soilborne disease. This may allow for the effective exploitation of the phenomenon as a component of an alternative disease management protocol in agricultural ecosystems.

\section{Acknowledgments}

This material is based upon work supported by the USDA National Research Initiative Competitive Grants Program under agreement number 2001-35319-09922. 


\section{References}

1. Amann, RI, Ludwig, W, Schleifer, KH (1995) Phylogenetic identification and in situ detection of individual microbial cells without cultivation. Microbiol Rev 59: 143-169

2. Amir, H, Alabouvette, C (1993) Involvement of soil abiotic factors in the mechanisms of soil suppressiveness to Fusarium wilts. Soil Biol Biochem 25: 157-164

3. Bull, CT, Weller, DM, Thomashow, LS (1991) Relationship between root colonization and suppression of Gaeumannomyces graminis var. tritici by Pseudomonas fluorescens strain 2-79. Phytopathology 81: 954-959

4. Cook, RJ, Baker, KF (1983) The Nature and Practice of Biological Control of Plant Pathogens. Am Phytopathol Soc, St Paul, MN

5. Dalmastri, C, Chiarini, L, Cantale, C, Bevivino, A, Tabacchioni, S (1999) Soil type and maize cultivar affect the genetic diversity of maize root-associated Burkholderia cepacia populations. Microb Ecol 38: 273-284

6. Felsenstein, J (1993) PHYLIP: Phylogeny Inference Package, Version 3.5c. Department of Genetics, University of Washington, Seattle

7. Grayston, SJ, Wang, S, Campbell, CD, Edwards, AC (1998) Selective influence of plant species on microbial diversity in the rhizosphere. Soil Biol Biochem 30: 369-378

8. Gu, Y-H, Mazzola, M (2003) Modification of fluorescent pseudomonad community and control of apple replant disease induced in a wheat cultivar-specific manner. Appl Soil Ecol 24: 57-72

9. Johnson, KB (1994) Dose-response relationships and inundative biological control. Phytopathology 84: 780-784

10. Keel, C, Schnider, U, Maurhofer, M, Voisard, C, Laville, J, Burger, P, Wirthner, P, Haas, D, Défago, G (1992) Suppression of root diseases by Pseudomonas fluorescens CHA0: importance of the secondary metabolite 2,4-diacetylphlorglucinol. Mol Plant-Microbe Interact 5: 4-13

11. Kumar, S, Tamura, K, Jakobsen, IB, Nei, M (2001) MEGA2: Molecular Evolutionary Genetics Analysis Software. Arizona State University, Tempe, AZ

12. Kuske, CR, Ticknor, LO, Miller, ME, Dubar, JM, Davis, JA, Barns, SM, Belnap, J (2002) Comparison of soil bacterial communities in rhizospheres of three plant species and the interspaces in an arid grassland. Appl Environ Microbiol 68: 1854-1863

13. Landa, BB, Mavrodi, OV, Raaijmakers, JM, McSpaden Gardener, BB, Thomashow, LS, Weller, DM (2002) Differential ability of genotypes of 2,4-diacetylphloroglucinol-producing Pseudomonas fluorescens strains to colonize the roots of pea plants. Appl Environ Microbiol 68: 3226-3237

14. Landa, BB, Mavrodi, DM, Thomashow, LS, Weller, DM (2003) Interactions between strains of 2,4-diacetylphloroglucinol-producing Pseudomonas fluorescens in the rhizosphere of wheat. Phytopathology 93: 982-994

15. Larkin, RP, Hopkins, DL, Martin, FN (1993) Effect of successive watermelon plantings on Fusarium oxysporum and other microorganisms in soils suppressive and conducive to Fusarium wilt of watermelon. Phytopathology 72: 247-251

16. Latour, X, Corberand, T, Laguerre, G, Allard, F, Lemanceau, P (1996) The composition of fluorescent pseudomonad populations associated with roots is influenced by plant and soil type. Appl Environ Microbiol 62: 2449-2456

17. Lemanceau, P, Corberand, T, Gardan, L, Latour, X, Laguerre, G, Boeufgras, J-M, Alabouvette, C (1995) Effect of two plant species, flax (Linum usitatissinum L.) and tomato (Lycopersicon esculentum Mill.) on the diversity of soilborne populations of fluorescent pseudomonads. Appl Environ Microbiol 61: 10041012
18. Liu, L, Kloepper, JW, Tuzun, S (1995) Induction of systemic resistance in cucumber by plant growth-promoting rhizobacteria; duration of protection and effect of host resistance on protection and root colonization. Phytopathology 85: 1064-1068

19. Liu, S, Baker, R (1980) Mechanism of biological control in soil suppressive to Rhizoctonia solani. Phytopathology 70: 404-412

20. Lugtenberg, BJJ, Dekkers, L, Bloemberg, GV (2001) Molecular determinants of rhizosphere colonization by Pseudomonas. Ann Rev Phytopathol 39: 461-490

21. Maurhofer, M, Keel, C, Haas, D, Défago, G (1995) Influence of plant species on disease suppression by Pseudomonas fluorescens CHA0 with enhanced antibiotic production. Plant Pathol 44: 4450

22. Mazzola, M (1998) Elucidation of the microbial complex having a causal role in the development of apple replant disease in Washington. Phytopathology 88: 930-938

23. Mazzola, M (1999) Transformation of soil microbial community structure and Rhizoctonia-suppressive potential in response to apple roots. Phytopathology 89: 920-927

24. Mazzola, M (2002) Mechanisms of natural soil suppressiveness. Antonie van Leeuwenhoek 81: 557-564

25. Mazzola, M, Cook, RJ (1991) Effects of fungal root pathogens on the population dynamics of biocontrol strains of fluorescent pseudomonads in the rhizosphere of wheat. Appl Environ Microbiol 57: 2171-2178

26. Mazzola, M, Fujimoto, DK, Thomashow, LS, Cook, RJ (1995) Variation in sensitivity of Gaeumannomyces graminis to antibiotics produced by fluorescent Pseudomonas spp. and effect on biological control of take-all of wheat. Appl Environ Microbiol 61: 25542559

27. Mazzola, M, Gu, Y-H (2000) Impact of wheat cultivation on microbial communities from replant soils and apple growth in greenhouse trials. Phytopathology 90: 114-119

28. Mazzola, M, Gu, Y-H (2002) Wheat genotype-specific induction of soil microbial communities suppressive to Rhizoctonia solani AG 5 and AG 8. Phytopathology 92: 1300-1307

29. McSpadden Gardener, BB, Schroeder, KL, Kalloger, SE, Raaijmakers, JM, Thomashow, LS, Weller, DM (2000) Genotypic and phenotypic diversity of phlD-containing Pseudomonas strains isolated from the rhizosphere of wheat. Appl Environ Microbiol 66: 1939-1946

30. McSpadden Gardener, BB, Mavrodi, DV, Thomashow, LS, Weller, DM (2001) A rapid polymerase chain reaction-based assay characterizing rhizosphere populations of 2,4-diacetylphloroglucinolproducing bacteria. Phytopathology 91: 44-54

31. Miethling, R, Wieland, G, Backhaus, H, Tebbe, CC (2000) Variation of microbial rhizosphere communities in response to crop species, soil origin, and inoculation with Sinorhizobium meliloti L33. Microb Ecol 41: 43-56

32. Nicholas, KB, Nicholas, HB (1997) Genedoc: A Tool for Editing and Annotating Multiple Sequence Alignments. Source: www.psc.edu/ biomed/genedoc

33. Nowak-Thomspson, B, Gould, SJ, Kraus, J, Loper, JE (1994) Production of 2,4-diacetylphloroglucinol by the biocontrol agent Pseudomonas fluorescens Pf-5. Can J Microbiol 40: 10641066

34. Notz, R, Maurhofer, M, Schnider-Keel, U, Duffy, B, Haas, D, Défago, G (2001) Biotic factors affecting expression of the 2,4diacetylphloroglucinol biosynthesis gene phlA in Pseudomonas fluorescens biocontrol strain CHA0 in the rhizosphere. Phytopathology 91: 873-881

35. Okubara, PA, Landa, BB, Madsen, B, Kornoely, JP (2002) Wheat cultivar-dependent root architecture and root colonization by $P$. fluorescens Q8r1. Phytopathology 92: S61 
36. Picard, C, Bosco, M (2003) Genetic diversity of phlD gene from 2,4-diacetylphloroglucinol-producing Pseudomonas spp. strains from the maize rhizosphere. FEMS Microbiol Lett 219: 167-172

37. Pierson, EA, Weller, DM (1994) Use of mixtures of fluorescent pseudomonads to suppress take-all and improve growth of wheat. Phytopathology 84: 940-947

38. Raaijmakers, JM, Bonsai, RF, Weller, DM (1999) Effect of population density of Pseudomonas fluorescens on production of 2,4diacetylphloroglucinol in the rhizosphere of wheat. Phytopathology 89: $470-475$

39. Raaijmakers, JM, Leeman, M, van Oorschot, MMP, Van der Sluis, I, Schippers, B, Bakker, PAHM (1995) Dose-response relationships in biological control of Fusarium wilt of radish by Pseudomonas spp. Phytopathology 85: 1075-1081

40. Raaijmakers, J, Weller, DM, Thomashow, LS (1997) Frequency of antibiotic-producing Pseudomonas spp. in natural environments. Appl Environ Microbiol 63: 881-887

41. Raaijmakers, JM, Weller, DM (1998) Natural plant protection by 2,4-diacetylphloroglucinol-producing Pseudomonas spp. in take-all decline soils. Mol Plant-Microbe Interact 11: 144-152

42. Raaijmakers, JM, Weller, DM (2001) Exploiting genotypic diversity of 2,4-diacetylphloroglucinol-producing Pseudomonas spp.: characterization of superior root colonizing $P$. fluorescens strain Q8r1 M-96. Appl Environ Microbiol 63: 881-887

43. Ramette, A, Moënne-Loccoz, Y, Défago, G (2001) Polymorphism of the polyketide synthase gene phlD in biocontrol fluorescent Pseudomonas producing 2,4-diacetylphloroglucinol and comparison of PhlD with plant polyketide synthases. Mol Plant-Microbe Interact 14: 639-652

44. Shipton, PJ (1975) Take-all decline during cereal monoculture. In: Bruehl, GW (Ed.) Biology and Control of Soil-Borne Plant Pathogens, Am Phytopathol Soc, St Paul, MN, pp 137-144
45. Simon, A, Ridge, EH (1974) The use of ampicillin in a simplified selective medium for the isolation of fluorescent pseudomonads. J Appl Bacteriol 37: 459-460

46. Smith, KP, Handelsman, J, Goodman, RM (1997) Modeling doseresponse relationships in biological control: partitioning host responses to the pathogen and biocontrol agent. Phytopathology 87: 720-729

47. Smith, KP, Handelsman, J, Goodman, RM (1999) Genetic basis in plants for interactions with disease-suppressive bacteria. Proc Natl Acad Sci USA 96: 4786-4790

48. de Souza, JT, Weller, DM, Raaijmakers, JM (2003) Frequency, diversity, and activity of 2,4-diacetylphloroglucinol-producing fluorescent Pseudomonas spp. in Dutch take-all decline soils. Phytopathology 93: 54-63

49. Tamietti, G, Alabouvette, C (1986) Resistance des sols aux maladies: XIII-Rôle des Fusarium oxysporum nonpathogenes dans les méchanismes de résistance d'un sol de Noirmoutier aux fusarioses vasculaires. Agronomie 6: 541-548

50. Thompson, JD, Higgins, DG, Gibson, TJ (1994) CLUSTAL W: improving the sensitivity of progressive multiple alignment through sequence weighting, positions-specific gap penalties and weight matrix choice. Nucleic Acids Res 22: 46734680

51. Weller, DM (1988) Biological control of soilborne plant pathogens in the rhizosphere with bacteria. Ann Rev Phytopathol 26: 379-407

52. Weller, DM, Raaijmakers, JM, McSpadden Gardener, BB, Thomashow, LS (2002) Microbial populations responsible for specific soil suppressiveness to plant pathogens. Ann Rev Phytopathol 40: 309-348

53. Whipps, JM (2001) Microbial interactions and biocontrol in the rhizosphere. J Exp Bot 52: 487-511 